\title{
Patients' knowledge about medication prescription in the emergency service
}

\author{
Conhecimento dos pacientes sobre a prescrição medicamentosa no serviço de emergência \\ Conocimiento de los pacientes sobre la prescripción farmacológicaen el servicio de urgencia
}

\section{Thaynara Paola de Carvalho', Meiry Fernanda Pinto Okuno", Cassia Regina Vancini Campanharo", Maria Carolina Barbosa Teixeira Lopes", Ruth Ester Assayag Batista'}

' Universidade Federal de São Paulo, Multi-professional Residency in Urgency and Emergency. São Paulo, Brazil.

"Universidade Federal de São Paulo, Paulista Nursing School, Department of Nursing. São Paulo, Brazil.

How to cite this article:

Carvalho TP, Okuno MFP, Campanharo CRV, Lopes MCBT, Batista REA. Patients' knowledge about medication prescription in the emergency service. Rev Bras Enferm [Internet]. 2018;71(2):329-35. DOI: http://dx.doi.org/10.1590/0034-7167-2017-0002

Submission: 02-20-2017 Approval: 05-08-2017

\section{ABSTRACT}

Objective: To identify which orientations were received by the patient about the medication prescription and which professional performed it; to evaluate the patients' knowledge about prescription drugs and to correlate it to socioeconomic variables, comorbidities, and the frequency with which the patient seeks emergency service; and to evaluate the knowledge about the medication prescribed after the health care. Method: This was a cross-sectional study on 304 patients that received emergency service's discharge along with medication prescription. Applied instruments: sociodemographic characterization and evaluation of the knowledge about the prescribed medication. We used a descriptive and inferential analysis. Results: Most subjects had no doubts about how or for how long to take the medication; and presented questions about adverse reactions and what to do in case of forgetting to take the medication doses. There was a significant association between age; educational level; comorbidity; the frequency of emergency service's use; and knowledge about medications. Conclusion: a total of $48 \%$ of the patients declared to need information about adverse effects and what to do if they forget to take the medication.

Descriptors: Knowledge; Medication Prescription; Emergency Care; Medical Emergency Service; Emergency Nursing.

\section{RESUMO}

Objetivo: Identificar quais orientações foram recebidas pelo paciente sobre prescrição medicamentosa e qual profissional as realizou; avaliar conhecimento dos pacientes sobre medicamentos prescritos; e correlacioná-lo às variáveis socioeconômicas, comorbidades e frequência com que o paciente procura o serviço de emergência com o conhecimento sobre medicamentos prescritos após o atendimento. Método: Estudo transversal e analítico com 304 pacientes que receberam alta do serviço juntamente com prescrição medicamentosa. Instrumentos aplicados: caracterização sócio demográfica e avaliação do conhecimento sobre a medicação prescrita. Utilizou-se análise descritiva e inferencial. Resultados: A maioria não teve dúvida sobre como nem por quanto tempo tomar o medicamento; e apresentou dúvidas sobre reações adversas e o que fazer no caso de esquecimento de doses do medicamento. Associação significativa entre idade; escolaridade; comorbidade; usuário frequente do serviço de emergência e conhecimento sobre medicamentos. Conclusão: Dos pacientes, $48 \%$ declararam precisar de informações sobre efeitos adversos e sobre o que fazer se esquecerem de fazer uso do medicamento.

Descritores: Conhecimento; Prescrição de Medicamentos; Atendimento de Emergência; Serviço Médico de Emergência; Enfermagem em Emergência.

\section{RESUMEN}

Objetivo: Identificar cuales las orientaciones fueron recibidas por el paciente sobre la prescripción farmacológica y cual profesional las realizó; evaluar el conocimiento de los pacientes sobre las medicinas prescriptas; y correlacionarlo a las variables socioeconómicas, las comorbidades y la frecuencia con que el paciente busca el servicio de urgencia con el conocimiento sobre las medicinas prescriptas después de la atención. Método: Estudio transversal y analítico con 304 pacientes que recibieron alta del servicio juntamente con la prescripción farmacológica. Instrumentos aplicados: caracterización socio demográfica y evaluación del conocimiento sobre la medicina prescrita. Se utilizó el análisis descriptivo e inferencial. Resultados: la mayoría 
no tuvo duda sobre cómo ni por cuanto tiempo tomar la medicina; y presentó dudas sobre las reacciones adversas y qué hacer en el caso de olvido de las dosis de la medicina. Asociación significativa entre laedad; la escolaridad; la comorbidad; el usuario frecuente del servicio de urgencia y el conocimiento sobre las medicinas. Conclusión: De los pacientes, el $48 \%$ declararon precisar de informaciones sobre los efectos adversos y sobre qué hacer si olvid anhacer uso de la medicina.

Descriptores: Conocimiento; Prescripción de Medicinas; Atención de Urgencia; Servicio Médico de Urgencia; Enfermería en Urgencia.

\section{CORRESPONDING AUTHOR Meiry Fernanda Pinto Okuno E-mail: mf.pinto@unifesp.br}

\section{INTRODUCTION}

Emergency services are among the most requested services and, consequently, the most overcrowded of the hospital sectors $^{(1)}$. Evidences point to a direct and consistent relation between overcrowding and the compromising of quality in the assistance provided in emergency services ${ }^{(2-3)}$. Thus, primary factors, such as health education and proper orientation of patients, are essential to a safe assistance ${ }^{(4)}$.

Most patients who resort to those services receive, after the medical treatment, a medication prescription and treatment orientations for the adequate follow-up at home ${ }^{(1)}$. For such, individuals have the need to adequately receive and appropriate themselves of these orientations, which should be offered individually and with quality.

There are numerous obstacles for the patients to have a full knowledge about the medical staff's information, aimed to prepare them to self-care. Mainly the complex environment of the emergency services, which does not favor written or verbal communication between health professional and patient; among other obstacles such as the low educational level of the attended public ${ }^{(1)}$.

Studies have pointed as major difficulties for the patient to follow the treatment at home the low understanding of the prescribed medication and offered information. These difficulties could jeopardize the health restoration and the prevention of damages and further harm ${ }^{(5-6)}$.

It is necessary to emphasize the importance of providing information to the patients, in such a way that they hold the greatest knowledge possible about their health conditions, the orientations that favor their clinic evolution, and, in particular, the medications to avoid possible complications ${ }^{(5)}$.

Knowledge about the medication is defined as the information obtained by the patient on the correct use, which includes name, dosage, times to take it, usage time, conservation methods, therapeutic goal, besides possible medication interactions and adverse reactions ${ }^{(7)}$.

Given this context, our study becomes important, inasmuch as it deals with the knowledge the patient has about the medication prescription, after attendance in an emergency service. Adherence or not to treatment brings an immense impact on morbidity and mortality of people affected by diseases that were not properly handled. Identifying the difficulties and needs regarding medical prescription, for patients treated by the emergency service, allows changes and improvements to be performed in the care provided. Thus, it contributes to the improvement of assistance effectiveness, preventing risks, complications, and even the early return of the user to the emergency service.
Our study aimed to identify which orientations were received by patients about medication prescription and which professional performed it; to evaluate the patients' knowledge about prescribed medication after care; and to correlate it to socioeconomic variables, comorbidities, and the frequency with which patients seek emergency service; and to evaluate the knowledge about the medication prescribed after emergency service.

\section{METHOD}

\section{Ethical aspects}

This study was approved by the Research Ethics Committee of the Federal University of São Paulo.

\section{Study design, location, and period}

Cross-sectional and analytical study, carried out in the emergency service of Hospital São Paulo (HSP), in São Paulo (SP), Brazil, between May and August 2016.

\section{Study sample; inclusion and exclusion criteria}

The sample of the study was for convenience. A total of 304 patients were included, who received medical prescription after emergency service's discharge, were over the age of 18 years and had no cognitive deficits or hearing and expression difficulties, according to information in the patient's chart. All of the subjects accepted to participate in the study and signed an informed consent form. The patients who did not meet the study inclusion criteria were excluded.

\section{Study protocol}

To obtain the data, we used a structured questionnaire, elaborated by the researchers, with information on age, gender, educational level, occupation, monthly household income, comorbidities, use of medication at home, medication(s) prescribed in the interviewing day, and how many times they sought the emergency service in the last year.

In addition, a questionnaire was drawn up from the instrument proposed by Fröhlich et $\mathrm{al}^{(8)}$. and adapted to this research. This questionnaire contained information on the patient's knowledge about the use of the prescribed medication after the emergency service discharge, such as: name of the medication; reason of prescription; dosage; usage times and period; administration method; what to do in case of forgetting to take one or more doses of medication; if there was any other medication, food or drink to avoid during the medicine usage; adverse effects; if the patient needed more information on the use of medication; if information was provided about it; and which professional offered this information ${ }^{(8)}$. 
When the prescription presented more than one medication, the answers were considered correct if the patient knew how to answer, at least, the information about half the prescribed drugs. If the patient had an accompaniment, the questionnaire was carried out with those responsible for the medication administration and the observation of the patient's clinical evolution.

\section{Analysis of results and statistics}

Descriptive analysis was used for the socioeconomic, demographic and comorbidities' characterization. For continuous variables, we calculated mean, standard deviation, median, minimum, and maximum. For the categorical variables, absolute and relative frequencies were calculated. To verify which independent variables (socioeconomic, comorbidities and frequency of service usage) better related to the patients' knowledge about the medication prescribed after emergency service attendance we used the Pearson Chi-square Test and the Kruskal-Wallis Test.

The significance level considered was $p<0.05$. The program used for analysis was the Statistical Package for the Social Sciences (SPSS), version 23.0 version 19.

\section{RESULTS}

The sample was composed of 304 patients, of which the mean age was 46 years with a standard deviation of \pm 15 . There was predominance of women; with complete or incomplete high school education; household income between one or two minimum wages; not smokers or alcoholics; with frequency in the emergency service of 1 to 3 times last year. This can be seen in Table 1.

In Table 2 it can be found the information the patients had, in the emergency service's discharge, about the prescribed medication. We identified that, from the 304 patients in the study, 297 received some information about the prescribed medication. Among those, 290 (97.65\%) were oriented by doctors, 4 $(1.35 \%)$ by nurses and $3(1.00 \%)$ by technicians and nursing assistants. Only 7 of these patients were oriented by more than one professional from the emergency service. We also observed that most patients knew, in the moment of hospital discharge, the reason that medication was prescribed; how and when to take the medication, and for how long to take it. Less frequent were the orientations regarding the possibility of some adverse reaction and what should be done if the patient forgets to take one or more doses of the medication. It should be highlighted that more than $48 \%$ of the study participants thought they needed more information about the medication prescription at the time of emergency service discharge.

After the patients' attendance in the emergency service, the researchers evaluated their knowledge about the prescribed medication. Most patients had no doubt about how to take the prescribed medication $(77.96 \%)$ or for how long to take it $(78.95 \%)$. There were questions about possible adverse reactions caused by the medication (95.72\%) and about what should be done in case of forgetting to take one or more doses of it $(98.03 \%)$.
Table 1 - Sociodemographic, economic and comorbidities characteristics, and search for emergency service among the study participants, São Paulo, Brazil, $2016(\mathrm{~N}=304)$

\begin{tabular}{|c|c|c|}
\hline Characteristics & $\mathbf{n}$ & $\%$ \\
\hline \multicolumn{3}{|l|}{ Sex } \\
\hline Male & 119 & 39.14 \\
\hline Female & 185 & 60.86 \\
\hline \multicolumn{3}{|l|}{ Educational level } \\
\hline Illiterate/Some elementary or middle school & 74 & 24.67 \\
\hline Elementary or Middle School & 44 & 14.47 \\
\hline High School/Some High School & 138 & 45.07 \\
\hline College degree/Some college & 48 & 15.79 \\
\hline \multicolumn{3}{|l|}{ Occupation } \\
\hline Employee & 187 & 61.52 \\
\hline Unemployed & 17 & 5.59 \\
\hline Retiree/Pensioner & 59 & 19.41 \\
\hline Student & 14 & 4.60 \\
\hline Homemaker & 27 & 8.88 \\
\hline Monthly household income* & 6 & 1.97 \\
\hline$<1$ & 6 & 1.97 \\
\hline 1 to 2 & 168 & 55.27 \\
\hline 3 to 5 & 113 & 37.17 \\
\hline$>5$ & 17 & 5.59 \\
\hline \multicolumn{3}{|l|}{ Smoker } \\
\hline Yes & 54 & 17.77 \\
\hline No & 250 & 82.24 \\
\hline \multicolumn{3}{|l|}{ Alcoholic } \\
\hline Yes & 9 & 2.96 \\
\hline No & 295 & 97.04 \\
\hline \multicolumn{3}{|l|}{ Frequency of emergency service usage in the last year } \\
\hline None & 26 & 8.55 \\
\hline $1-3$ times & 163 & 53.62 \\
\hline 4 times or more & 115 & 37.83 \\
\hline
\end{tabular}

Note: $*$ The household income is given in minimum wage $(M W)(1 M W=R \$ 880,00)$

A statistically significant association was perceived between the factors concerned in Table 3 (age and educational level) and the knowledge about the prescribed medications after emergency service care.

The higher the age of the study's patient, the higher their knowledge about dosage and usage time of the prescribed medication.

The higher the educational level of the participant, the better their knowledge about dosage, usage period and time to take the prescribed medication.

There was also a statistically significant association between the factors in Table 4 (age, educational level, the presence of comorbidity, and the number of visits to emergency service) and the knowledge about the medication prescribed after emergency service's care. 
Table 2 - Patients knowledge about the medication prescribed in the emergency service discharge, São Paulo, Brazil, $2016(\mathrm{~N}=304)$

\begin{tabular}{lcc}
\hline \multirow{2}{*}{ Received information } & Yes & No \\
\cline { 2 - 3 } & $\mathbf{n}(\%)$ & $\mathbf{n}(\%)$ \\
\hline Name of the prescribed medication & $138(45.39)$ & $166(54.61)$ \\
Reason the medication was prescribed & $280(92.11)$ & $24(7.89)$ \\
Dose to be taken & $107(35.20)$ & $197(64.80)$ \\
Times the medication must be taken & $223(73.36)$ & $81(26.64)$ \\
Period (s)he should make use of medication & $240(78.95)$ & $64(21.05)$ \\
Method of administration & $237(77.96)$ & $57(22.04)$ \\
What to do if (s)he forgets one or more doses & $5(1.97)$ & $298(98.03)$ \\
Most common adverse effects & $13(4.28)$ & $291(95.72)$ \\
Need more information about the prescribed medication & $147(48.36)$ & $157(51.64)$ \\
Some professional provided information on the prescribed medication & $297(97.70)$ & $7(2.30)$ \\
\end{tabular}

Table 3 - Socioeconomic variables associated with patients' knowledge about the medication prescribed in the emergency service, São Paulo, SP, Brazil, $2016(N=304)$

\begin{tabular}{lc}
\hline Variables & $\boldsymbol{p}$ value \\
\hline Age and knowledge of the medication dose & $<0.01^{*}$ \\
Age and knowledge of the medication usage period & $0.01^{*}$ \\
Educational level and knowledge of the medication dose & $<0.01^{*}$ \\
Educational level and knowledge about the time to take the medication & $<0.01^{*}$ \\
Educational level and knowledge about the medication usage period & $0.03^{*}$ \\
\hline
\end{tabular}

Note: Pearson Chi-square Test

Table 4 - Clinical variables associated with patients' knowledge about the medication prescribed in the emergency service, São Paulo, SP, Brazil, Brazil, 2016, (N=304)

\begin{tabular}{lc}
\hline Variables & $p$ value \\
\hline Age and knowledge of the medication dose & $<0.01^{*}$ \\
Age and knowledge of the medication usage period & $0.01^{*}$ \\
Educational level and knowledge of the medication dose & $<0.01^{*}$ \\
Educational level and knowledge about times to take the medication & $<0.01^{*}$ \\
Educational level and knowledge about duration of medication treatment & $0.03^{*}$ \\
Presence of comorbidity and knowledge about the medication prescription & $0.04^{*}$ \\
$\begin{array}{l}\text { Presence of comorbidity and knowledge about the attitude in case of forgetting } \\
\text { the medication dose }\end{array}$ & $<0.01^{*}$ \\
Presence of comorbidity and need to receive information about the \\
prescribed medication \\
$\begin{array}{l}\text { Number of visits to the emergency service in the last year and knowledge about } \\
\text { the medication prescribed } \\
\text { Number of visits to the emergency service in the last year and knowledge about } \\
\text { the medication indication } \\
\begin{array}{l}\text { Number of visits to the emergency service in the last year and knowledge about } \\
\text { the medication dose } \\
\text { Number of visits to the emergency service in the last year and a knowledge } \\
\text { about times to take the prescribed medication }\end{array}\end{array}$ \\
\hline
\end{tabular}

Notes: *Pearson Chi-square Test, **Kruskal-Wallis Test
Patients with previous comorbidities presented the desire for more information about the medication, as well as a greater knowledge of the prescribed drugs and of what to do in case of forgetting to take it.

Patients who sought emergency service more frequently presented a higher knowledge of the prescribed medication, indication, dosage, and the times to take the medication.

\section{DISCUSSION}

Medications became indispensable for the health recovery in most situations. However, they are not risk-free and may become dangerous when used inappropriately, which makes them a major problem in public health worldwide. Insufficient knowledge and the patients' lack of information about their medication result in great difficulties to correct drug therapy conduction, causing treatment ineffectiveness or even severe complications ${ }^{(6)}$.

Health education is highlighted in several studies as a crucial tool for harm control, especially regarding patients with chronic diseases ${ }^{(9-10)}$. Thus, it is fundamental to implement measures and to develop studies that prove the development of health education actions in the emergency services is able to reduce the early return to service, poor adherence hospitalization, and disease- or treatmentrelated complications.

The environment of emergency services, most of the time, does not favor the interaction between health professional and patient, both due to the momentum of this type of service and to the turnover of patients and professionals ${ }^{(1,11)}$. This compromises the effective development of health education, which is a primary action in the emergency service to favor the health-disease process and to avoid complications.

Thereby, the satisfactory patients' knowledge about the medication prescribed at the emergency discharge is important to highlight during the care, because it is a strategy to improve recovery and to avoid harms to health ${ }^{(5)}$. 
Some characteristics of this study sample - such as a mean of 46 years, women predominance, with complete or some High School, household income between 1 and 2 minimum wages were partly similar to the results found in another research. That research verified patients' knowledge about medications prescribed in the clinical and surgical wards of a University Hospital, in Juiz de Fora - MG. According to it, the patients presented a mean age of 44 years, most were women, with household income of 1 minimum wage and some High School ${ }^{(12)}$.

In our study, the evaluation of patients' knowledge about medication prescribed at the moment of emergency department's discharge showed a knowledge deficit, especially regarding the possibility of adverse reaction and the actions that should be taken in case of forgetting to take one or more doses of the medication. Another study, which evaluated patients' knowledge at the time of hospital discharge from the emergency service, verified the low knowledge regarding the orientations about the prescribed medication, the domiciliary self-care, and the instructions about signs and warning symptoms to return to the hospital ${ }^{(5)}$.

Like this study, that research was conducted in the primary attention to health, evaluated the patients' knowledge level as insufficient, and showed the need of information about adverse reactions and what to do in case of forgetting one or more doses of the prescribed medication. This corroborates the findings of our study ${ }^{(1)}$.

In our study, we found that the higher the patients' age, the higher their knowledge about dosage and usage time of the prescribed medication. This may be related to the fact that older people usually make use of continuous medications, which might be associated with greater knowledge ${ }^{(13)}$. A distinct result was found in another study, carried out with Unified Health System users in the municipality of Tubarão, Santa Catarina, Brazil, in which younger people understood the medication prescription better, when compared with older people ${ }^{(13)}$.

In this study, it can be observed that the higher the educational level of the participant, the greater was the knowledge about dosage, and time and period of medication usage; which is confirmed in the literature through several studies, developed in diverse health attention levels ${ }^{(1,8)}$. The knowledge might be related to the patient's comprehension concerning the offered orientations. The low educational level can be an obstacle to the information understanding ${ }^{(13)}$. The educational level directly interferes in the development of sanitary awareness, in the ability to understand the prescribed treatment, and in the self-care practice ${ }^{(14)}$.

Our study shows that patients with previous comorbidity wished for more information about the medication, as well as presented more knowledge on the indication of the prescribed drugs and on what to do in case of forgetting to take it. However, in another study, which conducted a systematic review to evaluate the morbidity and mortality related to medications in Brazil, it was identified that the risk factors for the occurrence of morbimortality were age, presence of comorbidities, and the usage of more than five medications concomitantly ${ }^{(15)}$.

In this research, most patients had no doubts about how to take the prescribed medication or for how long to take it.
Patients who sought emergency service more frequently presented a higher knowledge about the prescribed medication, indication, dosage, and the medication usage times. These results may be related to the activities developed by the emergency service - namely, medication reconciliation, orientation to the patient and/or caregiver - as strategies to minimize the risk of adverse events related to medication after hospital discharge. Such actions contribute to preventing damage to the patient and unnecessary costs to the health system.

Given this context, the importance of comprehension about the medication prescription is highlighted, since this can contribute to the health-disease process, favor treatment adherence and adequate usage of medication, which can prevent damage and harms to health.

The orientation the patients received from professionals, in this study, was provided in the verbal form. Another research, which characterized the patients' level of knowledge regarding medications prescribed in dental services, and verified the frequency of verbal prescriptions, observed that $36 \%$ of the patients who received verbal and written prescription remembered only of instructions given in the latter form ${ }^{(7)}$. Considering the lawful character attributed to the prescription, the practice of the verbal prescription leaves the professional in a vulnerable position. Besides, it puts the patient in a situation that is very close to self-medication, with risks of under- or over-dosage $^{(7)}$. It is therefore important that the emergency service develops an instrument to record the discharge orientation in the patient's chart, and to allow the patients to take it with them. Thus, the quality of the provided assistance and the patient's safety are improved.

\section{Study limitations}

The limitation of this study was the fact that it was carried out in an educational institution, which may not reflect the reality of other institutions of strictly assistant entail character.

\section{Contributions to the field of nursing}

The Emergency Service has long been considered a gateway to the health system in Brazil, which therefore results in the care of a large number of patients in these units. The knowledge of the orientations, provided about medication prescription to patients in emergency service discharge, can offer useful information to support professionals' reflections for new strategies planning. This can result in increased adherence and treatment effectiveness. In this sense, the nurse must adopt a starring role in the education of this population.

In the strategic planning of nursing care, we highlight the discharge planning as an indispensable tool to integral care during hospitalization and after hospital discharge, aiming the continuous patient's self-care at home. The nurse is the health professional who, during its professional training, is prepared to carry out educational and health activities, aiming the hospital discharge planning. Nevertheless, many times it is possible to observe the distance of this professional regarding its patients at this very important moment of hospital discharge ${ }^{(16)}$. Orientations to the patient are essential for the success in continuing treatment at home, since the insufficient knowledge about health problems is one 
of the main causes behind the patients' lack of adherence to the pharmacotherapeutic regimen and monitoring plan $^{(17)}$. This reality demands from the nurses the commitment and concern, not only with the patient but also with the preparation of the relatives to hospital discharge, always aiming to help them to obtain the greatest benefits with their medication usage; to assist in the resolution of existing problems; to prevent future problems, and to develop the individual capacity to deal with problems related to medication use that might occur at their domiciles ${ }^{(17)}$.

However, the hospital discharge planning should be primarily multi-professional, since the knowledge of each profession is necessary for the success of the post-discharge plan. To achieve that, these professionals must be present and recognizable. Besides, they must insert into their routines the patient orientation, not only in hospital discharge, but during the whole admission period ${ }^{(12)}$.

\section{CONCLUSION}

The majority of the study participants received information about the medication prescribed by an emergency service's professional. Most of the time, they were oriented by the medical staff. In the moment of discharge, most of the patients knew the reason for the medication prescription; however, $48 \%$ of them declared to need information on the possible adverse effects and on how to proceed in case of forgetting to use the medication. The higher the age and educational level of the patients, the higher was their knowledge about dosage and usage time of the prescribed medication.

Thus, we perceive the importance of establishing an orientation protocol for patients treated in the emergency service, in order to increase understanding about medication usage, and lead to better adherence and treatment effectiveness.

\section{REFERENCES}

1. Bulut H, Tanrıkulu G, Dal Ü, Kapucu S. How much do ED patients know about medication prescribed for them on discharge? a pilot study in Turkey. J Emerg Nurs[Internet]. 2013[cited 2017 Apr 26];39(3):27-32. Available from: https://www.ncbi.nlm.nih.gov/ pubmed/23647997

2. Di Somma S, Paladino L, Vaughan L, Lalle I, Magrini L, Magnanti M. Overcrowding in emergency department: an international issue. Intern Emerg Med[Internet]. 2015[cited 2017 Apr 26];10(2):171-5. Available from: https://www.ncbi.nlm.nih.gov/ pubmed/25446540

3. Oliveira DA, Guimarães JP. A importância do acolhimento com classificação de risco nos serviços de emergência. Cad Saúde Desenv[Internet]. 2013[cited 2017 Apr 26];2(2):25-44. Available from: http://www.uninter.com/revistasaude/index.php/ cadernosaudedesenvolvimento/article/view/197

4. Viola DC, Cordioli E, Pedrotti CH, lervolino M, Bastos Neto AS, Almeida LR, et al. Unidades avançadas: medidas de qualidade no atendimento de urgência e emergência. Einstein [Internet]. 2014[cited 2017 Apr 26];12(4):492-8. Available from: http://www. scielo.br/pdf/eins/v12n4/pt_1679-4508-eins-12-4-0492.pdf

5. Engel KG, Buckley BA, Forth VE, McCarthy DM, Ellison EP, Schmidt MJ, et al. Patient understanding of emergency department discharge instructions: where are knowledge deficits greatest? Acad Emerg Med[Internet]. 2012[cited 2017 Apr 26];19(9):1035-44. Available from: http://onlinelibrary.wiley. com/doi/10.1111/j.1553-2712.2012.01425.x/epdf

6. Pereira MV, Alencar JS, Souto RP, Pinto NB, Saraiva SEM. Grau de conhecimento dos pacientes sobre o tratamento: estratégia para uso racional de medicamentos. J Health NPEPS[Internet]. 2016[cited 2017 Apr 26];1(1):31-39. Available from: http://periodicos. unemat.br/index.php/jhnpeps/article/view/1557

7. Dresch AP, Amador TA, Heineck I. Conhecimento dos pacientes sobre medicamentos prescritos por odontólogos no sul do Brasil. Ciênc Saúde Colet[Internet]. 2016[cited 2017 Apr 26];21(2):475-83. Available from: http://www.scielo.br/pdf/csc/v21n2/14138123-csc-21-02-0475.pdf

8. Fröhlich SE, Pizzol TSD, Mengue SS. Instrumento para avaliação do nível de conhecimento da prescrição na atenção primária. Rev Saúde Pública[Internet]. 2010[cited 2017 Apr 26];44(6):1046-54. Available from: http://dx.doi.org/10.1590/S0034-89102010000600009

9. Gonçalves FG, Albuquerque DC. Educação em saúde de pacientes portadores de insuficiência cardíaca. Rev Enferm UERJ[Internet]. 2014[cited 2017 Apr 26];22(3):422-28. Available from: http://www.e-publicacoes.uerj.br/index.php/enfermagemuerj/article/ view/13769

10. McCarthy MD, Wolf MS, McConnell R, Sears J, Chevrier A, Ahlstrom E, et al. Patient knowledge and safe use of opioids: a randomized controlled trial. Acad Emerg Med[Internet]. 2015[cited 2017 Apr 26];22(3):331-39. Available from: http://onlinelibrary. wiley.com/doi/10.111 1/acem.12600/epdf

11. Gozdzialski A, Schlutow M, Pittiglio L. Patient and family education in the emergency department: how nurses can help. J Emerg Nurs[Internet]. 2012[cited 2017 Apr 26];38:293-95. Available from: http://www.jenonline.org/article/S0099-1767(11)00685-4/ abstract

12. Lupatini EO, Munck AKR, Bastos RR, Vieira RCPA. Conhecimento dos pacientes de um hospital de ensino a respeito dos medicamentos prescritos na alta. HU Rev[Internet]. 2016[cited 2017 Apr 26];42(4):315-322. Available from: https://hurevista.ufjf. emnuvens.com.br/hurevista/article/view/2609 
13. Cruzeta APS, Dourado ACL, Monteiro MTM, Martins RO, Calegario TA, Galato D. Fatores associados à compreensão da prescrição médica no Sistema Único de Saúde de um município do Sul do Brasil. Ciênc Saúde Colet[Internet]. 2013 [cited 2017 Apr 26];18(12):3731-37. Available from: http://dx.doi.org/10.1590/S1413-81232013001200029

14. Okuno MFP, Gomes AC, Meazzini L, Scherrer Jr G, Belasco Jr D. Qualidade de vida de pacientes idosos vivendo com HIV/AIDS. Cad Saúde Pública[Internet]. 2014[cited 2017 Apr 26];30(7):1551-59. Available from: http://www.scielo.br/pdf/csp/v30n7/0102311X-csp-30-7-1551.pdf

15. Souza TT, Godoy RR, Rotta I, Pontarolo R, Fernandez-Llimos F, Correr CJ. Morbidade e mortalidade relacionadas a medicamentos no Brasil: revisão sistemática de estudos observacionais. Rev Ciênc Farm Básica Apl[Internet]. 2014[cited 2017 Apr 26];35(4):51932. Available from: http://serv-bib.fcfar.unesp.br/seer/index.php/Cien_Farm/article/view/2971

16. Cruz IML, Mantovani MF. Orientação de enfermagem para a alta hospitalar do paciente neoplásico. Cogitare Enferm[Internet]. 2014[cited 2017 Apr 26];19(4):687-93. Available from: http://revistas.ufpr.br/cogitare/article/view/36261

17. Delatorre PG, Sá SPC, Valente GSC, Silvino ZR. Planejamento para a alta hospitalar como estratégia de cuidado de enfermagem: revisão integrativa. Rev Enferm UFPE[Internet]. 2013[cited 2017 Apr 26];7(esp):7151-9. Available from:www.revista.ufpe.br/ revistaenfermagem/index.php/revista/article/download/.../8170 